\title{
28 Research Square

\section{A Novel Optimized Formulation for Cooling Tower Effluent Disinfection: Tarasht Power Plant Case Study}

\section{Ehsan Sohrabi}

Isfahan University of Technology

\section{Somayeh Sohrabi}

Amirkabir University of Technology

Davood Iranshahi

Amirkabir University of Technology

\section{Majid Sarmadi}

Director of Chemical Affairs and member of the board of directors of Tarasht power plant

Mostafa Keshavarz Moraveji ( $\square$ moraveji@aut.ac.ir)

Amirkabir University of Technology

\section{Research Article}

Keywords: Cooling tower, Disinfection, Amoxicillin, Persulfate, Glucose Oxidase, Escherichia coli, antibiotic resistance

Posted Date: December 2nd, 2021

DOI: https://doi.org/10.21203/rs.3.rs-1110232/v1

License: (c) (i) This work is licensed under a Creative Commons Attribution 4.0 International License. Read Full License 


\section{Abstract}

Since the operating conditions of the cooling tower units provide such a suitable environment for the growth of bacteria and algae, taking measures for the disinfection process is strongly recommended. The cooling tower unit is proceeded by RO and the disinfection strategy is sodium hypochlorite, combined with this new formulation. The sampling result revealed that bacteria counts from the effluent of the cooling tower are $2600 \mathrm{CFU} / \mathrm{ml}$ while the microbial load of the water in the pond is $220 \mathrm{CFU} / \mathrm{ml}$. Herein, two type formulations are introduced for cooling tower output stream while the pond water comes along with a $\mathrm{NaOCl}$ injection. The dosage of A: Glucose Oxidase, B: ammonium persulfate, and C: Amoxicillin, and $D$ : the order of use are chosen as the four independent variables whose effects and their binary interactions on microbial load and disinfection efficiency were investigated via Box-Behnken design (BBD) combined with response surface methodology (RSM). The ANOVA results show that the most significant variable is amoxicillin in the presence of bleach. Meanwhile, high values for $R^{2}>0.99$ and the model F-value 45.64 in addition to diagnostic tests confirmed the reliability of the model. Several solutions have been introduced as optimum formulations. The pre-scale up and economic considerations have been included.

\section{Introduction}

Cooling tower is a general unit in power plants, chemical, petrochemical, and refining industries. The operational conditions in terms of temperature and humidity can provide a suitable environment for microorganisms' growth [1]. Suspended droplets and aerosols can deliver Legionella pneumophila bacteria into the respiratory system of operators working in this unit, which may be accompanied by Legionnaires' disease and death. Not only health problems but also the risk of biofilm formation and microbial corrosion in the system triggers motives for taking actions toward controlling the pathogens [24].

Sodium hypochlorite $(\mathrm{NaOCl})$ is an oxidizing agent, whose efficacy of disinfection decreases with an increase in $\mathrm{pH}$, likely due to the decreased proportion of hypochlorous acid group present [5]. The $\beta$ lactam antimicrobials show time-dependent bacterial killing with minimal to no persistent effects [6]. Most bacteria are also sensitive to quaternary ammonium. Moreover, bactericidal and virucidal efficacies of potassium monopersulfate are also reported [7]. Hydrogen peroxide is a potent, effective, and safe broad-spectrum biocide which unlike other biocides, considerably reduces any risk of the development of resistance to the biocide over time $[5,8]$. The performance of the pilot-scale UV / $\mathrm{H}_{2} \mathrm{O}_{2}$ system in the treatment of sulfolane contaminated groundwater in a reservoir with a volume of $5.6 \mathrm{~m}^{3}$ with an optimal concentration of hydrogen peroxide was $40 \mathrm{mg} / \mathrm{l}$ [9]. A pilot-scale study on the application of hydrogen peroxide for disinfecting Johns Hopkins Hospital curtains in the United States indicates that a concentration of $3.1 \%$ of hydrogen peroxide can remove $\mathrm{C}$. difficile, MRSA, and VRE bacteria with $100 \%$ efficiency [10]. A fog solution containing $5 \% \mathrm{H}_{2} \mathrm{O}_{2}$ with $0.005 \%$ silver has been used as a disinfecting agent in the food industry to remove a mixture of four L. monocytogenes strains in a $36 \mathrm{~m}^{3}$ chamber [11]. 
The glucose oxidase (GOx) enzyme is a biomaterial and environmentally friendly, which ensures the production of hydrogen peroxide under normal conditions and at a low cost. In addition, it prevents the potential dangers of handling, transport, and storage of $\mathrm{H}_{2} \mathrm{O}_{2}$ [12]. Persulfate-based groundwater remediation is reported in which the objective has to study chloride, alkalinity, and pH impacts [13]. Persulfate-based AOPs have been claimed to embroil several in situ generated oxidants such as sulfate radical and singlet oxygen as well as nonradical oxidation pathways [14].

There are several reports from related research works stating that a multi-component is preferred to a single disinfecting agent. The combination of antibacterial agents shows more

powerful effects that enhance antibacterial activity [15]. Vázquez-Sánchez et al. (2018) have found that Lippia sidoides, Thymus vulgaris and Pimenta pseudochariophyllus oils were highly effective against both planktonic cells and the biofilm of L. monocytogenes. Additionally, the application of oils in binary combinations decreased the required doses to kill $99.99 \%$ of biofilm cells [16]. A promising effect of glucose oxidase in combination with antibiotics is confirmed [17]. Moreover, to prevent the adaptation of microbes in cooling tower environments, an occasional or periodic dose of an additional non-oxidizing biocide is recommended as a supplement [18]. Kyung Min Park et al. 2020, have invented a patent for disinfection formulation of utensil surfaces in the food industry based on R. officinalis, L. extract, C. sinensis L. extract, citric acid, and $\varepsilon$-polylysine. An additional compound, glycerin fatty acid ester [15].

However, there is no report on a multi-component based on the integrated antibiotic and a multi-oxidant mixture. This work is specifically designed for the cooling tower unit operating conditions with no changes on the current strategy of disinfection of the pond with $\mathrm{NaOCl}$. In this work, a ternary mixture of amoxicillin, ammonium persulfate, and glucose oxidase is modeled and optimized with a RSM-BBK design. Moreover, the binary interactions of the formulation components have been addressed. Finally, the equipment-free nature of the proposed method has been confirmed and the economic considerations are given.

\section{Materials And Methods \\ 2.1 Materials}

Nutrient Agar (ibresco) is used for the cultivation of microorganisms in water samples. Ammonium persulfate (97\%, Merk), Glucose oxidase (a gifted from Bonda Group Development), and amoxicillin trihydrate (a gift from Afa Chimi) are used as disinfection formulation components. $\beta$-D Glucose monohydrate ( $97 \%$, Sigma) has been employed as the substrate for GOx with a mass ratio of 1:1 for GOx/glucose. The abbreviations used for enzyme glucose oxidase: GOx, Ammonium persulfate: P.S., amoxicillin: Amox.

\subsection{The industrial-Scale system}


The full-scale system is located in Tarasht (Alstom) power plant, Tehran province, Iran. A $3000 \mathrm{~m}^{3}$ cooling tower pond is equipped with an online $\mathrm{pH}$ measuring system and a bleach tank, a $\mathrm{H}_{2} \mathrm{SO}_{4}$ injection tank, and an RO unit. The water upstream of the cooling tower is actually the output of the RO section, which has a water hardness of $600 \mathrm{ppm}$. In the pond, 4 tons of bleach is injected per week. The algae growth can be seen inside the cooling tower and other parts away from the bleach Since the $\mathrm{pH}$ of $\mathrm{NaOCl}$ is in the range of 11-13 and makes the water highly alkaline. By injecting 1 ton per day of $98 \%$ sulfuric acid, they keep the $\mathrm{pH}$ constant in the range of 8-9 tons per day. The system recirculates on average 3700 $\mathrm{m}^{3} / \mathrm{h}$ of cooling water and temperature in the cooling tower reaches $40^{\circ} \mathrm{C}$ and in the outlet, the water temperature is $30^{\circ} \mathrm{C}$. Biofilm growth was visually observed many parts that were out of reach sodium hypochlorite at the cooling tower walls and the metal columns supporting the cooling tower.

\subsection{Experimental}

A series of lab-scale tests have been designed by Response surface methodology (RSM) for this multivariate optimization to ensure a minimum number of experiments. For this aim, Box-Behnken has superiority over other methods by neglecting points in which all the factors are at the highest or the lowest levels at the same time [19]. According to standard 4207, the tests were conducted within $24 \mathrm{~h}$ after sampling. The multi constituent nature of the formulation enriches it against bacterial adaptation. The information on the variables levels are given in Table.1. According to the plan of experiments, a certain amount of each substance is wanted. The total reaction time is considered $120 \mathrm{~min}$ in which it is divided into three phases, the first 30 min, amoxicillin is participating the biocidal activity, In phase II, either GOx [formulation (GOx.2)] of persulfate [formulation P.S.2] is added and into the second 30 minutes, a binary antimicrobial agent is employed. Finally, the last 60 minutes from the start, the third component is introduced. Meanwhile, here not only the order of the addition of formulation components is considered, but also the single, binary, and ternary effects of each agent are addressed.

Table.1 Types and levels of formulation variables in RSM-BBD

\begin{tabular}{|c|c|c|c|c|c|c|c|c|c|c|}
\hline Factor & Name & Units & Type & $\begin{array}{l}\text { Sub } \\
\text { Type }\end{array}$ & Minimum & Maximum & $\begin{array}{c}\text { Coded } \\
\text { Low }\end{array}$ & $\begin{array}{c}\text { Coded } \\
\text { High }\end{array}$ & Mean & $\begin{array}{l}\text { Std. } \\
\text { Dev. }\end{array}$ \\
\hline $\mathbf{A}$ & AMOX & $\mathrm{mg} / \mathrm{L}$ & Numeric & Continuous & 0.0000 & 20.00 & $-1 \leftrightarrow 0.00$ & $\begin{array}{l}+1 \leftrightarrow \\
20.00\end{array}$ & 10.00 & 6.96 \\
\hline B & P.S. & $\mathrm{mg} / \mathrm{L}$ & Numeric & Continuous & 0.0000 & 20.00 & $-1 \leftrightarrow 0.00$ & $\begin{array}{l}+1 \leftrightarrow \\
20.00\end{array}$ & 10.00 & 6.96 \\
\hline $\mathrm{C}$ & GOx & $\mathrm{mg} / \mathrm{L}$ & Numeric & Continuous & 0.0000 & 20.00 & $-1 \leftrightarrow 0.00$ & $\begin{array}{l}+1 \leftrightarrow \\
20.00\end{array}$ & 10.00 & 6.96 \\
\hline D & Order & - & Categorical & Nominal & GOx.2 & P.S. 2 & - & - & Levels: & 2.00 \\
\hline
\end{tabular}

\subsection{Analytical Methods}


According to standard ISIRI 4207 and pure plate method, we first add $1 \mathrm{ml}$ of the sample into a petri dish containing the nutrient agar medium for surface culture. Afterward, the plates are put into an incubator at $35^{\circ} \mathrm{C}$ for 24 hours, and finally the microbial load is counted with the colony count apparatus. It is assumed that after incubation, each microorganism proliferates and creates a visible colony on the solid culture medium.

The morphology of bacteria is investigated using a scanning electron microscope of Philips Netherlands, $\mathrm{XL} 30$ model at the acceleration voltage of $25 \mathrm{kV}$.

\section{Results}

\subsection{Sampling and Microbial Load}

Two places have been selected for sampling points, the first one is stagnant water in a pond downstream of the cooling tower where $\mathrm{NaOCl}$ is injected, and the second sample of recirculating water that is exposed to the air, which is the direct outlet of the cooling tower. Aerobic microbial counts and coliform counts for samples original samples and the ones with $10^{-1}$ dilution have been executed. For plate images, the first row in Fig. 1 is devoted to the direct output stream of cooling towers, and the second row is associated with the water samples in the pond. The results show that E.coli is not detected in samples and the total coliform test is negative. The results of bacterial counts of the original sample and the $10^{-1}$ dilution of the recirculating water are $2600 \mathrm{CFU} / \mathrm{ml}$ and $120 \mathrm{CFU} / \mathrm{ml}$, respectively. The bacterial counts of the main sample and the $10^{-1}$ dilution of water in the pond are $220 \mathrm{CFU} / \mathrm{ml}$ and $55 \mathrm{CFU} / \mathrm{ml}$, respectively. SEM image SEM electron microscopy image of bacteria in the water of the cooling tower unit of Tarasht power plant shows that the morphology of the bacteria is coco bacilli, which are between the cocci (spherical) and bacillus (rod-shaped) and are in the form of tiny rods as short as 2 microns.

\subsection{Disinfection with formulation components}

To determine the effectiveness of the formulation components, each was tested at different concentrations. Fig. 2 reveals that the antibacterial effect of the amoxicillin and glucose oxidase is analogous and more robust than persulfate. Antibiotics and amoxicillin exhibit similar performance against Escherichia coli 088 in [20]. Moreover, efficiencies above $90 \%$ were obtained for glucose oxidase and amoxicillin at doses of $20 \mathrm{mg} / \mathrm{I}$ and higher. The sharpest slope of the graphs are observed in the dosage range of lower than $20 \mathrm{mg} / \mathrm{l}$ and less, the use of antibiotics has a higher disinfection efficiency.

\subsection{Pre scale-up considerations}

To investigate how facile application of is to check whether further equipment is required to not, a number of tests have been considered which are as follows: Sample 1: without stirrer, sample 2: with the magnetic stirrer, sample 3: 10-fold scale increase in the volume of the water sample, sample 4: well water, sample 5: no Stirrer under sunlight, sample 6: aeration and irradiation with UVA light source, 40W, sample 7: aeration and with the magnetic stirrer under irradiation with UVA light source, 40W. The disinfection 
strategy is applying $50 \mathrm{mg} / \mathrm{l} \mathrm{GOx}$ for $0.2 \mathrm{~L}$ of the cooling tower output stream. According to the comparative results of samples 1-2 and 6-7 in Table.2, it can be concluded that installing a mixing tool is not needed in large-scale. Moreover, the positive effect of ultraviolet light on disinfection efficiency is $15 \%$ more than sunlight. Sunlight has $5 \%$ ultraviolet light and has a large share of visible and infrared irradiations. The importance of ultraviolet light is in breaking down hydrogen peroxide molecules and converting them to active hydroxyl radicals that destroy microbes. Comparing samples 2 and 4 , it can be concluded that in well water and cooling tower outlet water, although the microbial load after disinfection is almost the same, but since the number of primary bacteria in well water (sample 4) was less, the number of bacteria death is less than that of sample 2. This result indicates that the operating conditions of the cooling tower, in addition to providing the conditions for the growth of bacteria, also make them more sensitive to antibacterial agents.

Table.2 Different conditions for disinfection process with GOx

\begin{tabular}{|c|c|c|c|}
\hline$\#$ & Conditions & $\begin{array}{l}\text { Bacterial Counts } \\
\text { (CFU/ml) }\end{array}$ & $\begin{array}{c}\text { Disinfection } \\
\text { Efficiency (\%) }\end{array}$ \\
\hline 1 & Without stirrer & 373 & 85.65385 \\
\hline 2 & With magnetic stirrer & 418 & 83.92308 \\
\hline 3 & $\begin{array}{l}10 \text {-fold scale increase in volume of } \\
\text { water sample }\end{array}$ & 195 & 92.5 \\
\hline 4 & Well water & 415 & 56.81582 \\
\hline 5 & No Stirrer under sunlight & 846 & 67.46154 \\
\hline 6 & $\begin{array}{l}\text { Aeration/ irradiation with UVA light } \\
\text { source, } 40 \mathrm{~W}\end{array}$ & 449 & 82.73077 \\
\hline 7 & $\begin{array}{c}\text { Aeration/ with magnetic stirrer/ } \\
\text { irradiation with UVA light source, } \\
40 \mathrm{~W}\end{array}$ & 801 & 69.19231 \\
\hline
\end{tabular}

\subsection{Design of experiments}

Figure 2, shows the effectivity of amoxicillin, glucose oxidase, and ammonium persulfate as disinfecting agents upon the water within the cooling tower unit. The first three factors have been adopted for the concentration of amoxicillin, ammonium persulfate, glucose oxidase enzyme. These three substances in concentrations of $20 \mathrm{mg} / \mathrm{l}$ and less, have a significant effect on disinfection efficiency. Therefore, the experimental design can be guided by this information. There is a nominal variable, which is aimed to evaluate the importance of the order of addition the formulation components, with two levels are adjusted to prioritize where to apply glucose oxidase or persulfate as the second component. In this work, 
RSM combined with BBD design is utilized. The design point and the experimental values for bacterial counts and disinfection efficiency as R1 and R2 for 34 runs are presented in Table.3.

Table.3 Plan of experiments for evaluating the 4 factors on the R1 and R2

\begin{tabular}{|c|c|c|c|c|c|c|c|}
\hline & & $\begin{array}{c}\text { Factor } \\
1\end{array}$ & $\begin{array}{c}\text { Factor } \\
2\end{array}$ & $\begin{array}{c}\text { Factor } \\
3\end{array}$ & $\begin{array}{c}\text { Factor } \\
4\end{array}$ & $\begin{array}{c}\text { Response } \\
1\end{array}$ & $\begin{array}{c}\text { Response } \\
2\end{array}$ \\
\hline Std. & Run & A:AMOX & B:P.S. & $\mathrm{C}: \mathrm{GOx}$ & D:Order & $\begin{array}{c}\text { Bacterial } \\
\text { Counts }\end{array}$ & $\begin{array}{l}\text { Disinfection } \\
\text { Efficiency }\end{array}$ \\
\hline & & $\mathrm{mg} / \mathrm{L}$ & $\mathrm{mg} / \mathrm{L}$ & $\mathrm{mg} / \mathrm{L}$ & & $\mathrm{CFU} / \mathrm{ml}$ & $\%$ \\
\hline 25 & 1 & 20 & 10 & 20 & P.S. 2 & 69 & 97.3462 \\
\hline 17 & 2 & 10 & 10 & 10 & GOx.2 & 49 & 98.1154 \\
\hline 23 & 3 & 20 & 10 & 0 & P.S. 2 & 142 & 94.5385 \\
\hline 27 & 4 & 10 & 20 & 0 & P.S.2 & 55 & 97.8846 \\
\hline 15 & 5 & 10 & 10 & 10 & GOx.2 & 43 & 98.3462 \\
\hline 3 & 6 & 0 & 20 & 10 & GOx.2 & 69 & 97.3462 \\
\hline 20 & 7 & 0 & 20 & 10 & P.S. 2 & 274 & 89.4615 \\
\hline 24 & 8 & 0 & 10 & 20 & P.S.2 & 91 & 96.5 \\
\hline 19 & 9 & 20 & 0 & 10 & P.S. 2 & 126 & 95.1538 \\
\hline 34 & 10 & 10 & 10 & 10 & P.S. 2 & 8 & 99.6923 \\
\hline 11 & 11 & 10 & 0 & 20 & GOx.2 & 37 & 98.5769 \\
\hline 26 & 12 & 10 & 0 & 0 & P.S.2 & 80 & 96.9231 \\
\hline 29 & 13 & 10 & 20 & 20 & P.S. 2 & 10 & 99.6154 \\
\hline 32 & 14 & 10 & 10 & 10 & P.S.2 & 40 & 98.4615 \\
\hline 4 & 15 & 20 & 20 & 10 & GOx.2 & 3 & 99.8846 \\
\hline 16 & 16 & 10 & 10 & 10 & GOx.2 & 49 & 98.1154 \\
\hline
\end{tabular}




\begin{tabular}{|c|c|c|c|c|c|c|c|}
\hline $\mathbf{1 8}$ & 17 & 0 & 0 & 10 & P.S.2 & 8 & 99.6923 \\
\hline $\mathbf{9}$ & 18 & 10 & 0 & 0 & GOx.2 & 180 & 93.0769 \\
\hline $\mathbf{1 3}$ & 19 & 10 & 10 & 10 & GOx.2 & 40 & 98.4615 \\
\hline $\mathbf{6}$ & 20 & 20 & 10 & 0 & GOx.2 & 210 & 91.9231 \\
\hline $\mathbf{7}$ & 21 & 0 & 10 & 20 & GOx.2 & 6 & 99.7692 \\
\hline $\mathbf{5}$ & 22 & 0 & 10 & 0 & GOx.2 & 33 & 98.7308 \\
\hline $\mathbf{2}$ & 23 & 20 & 0 & 10 & GOx.2 & 21 & 99.1923 \\
\hline $\mathbf{8}$ & 24 & 20 & 10 & 20 & GOx.2 & 86 & 96.6923 \\
\hline $\mathbf{2 8}$ & 25 & 10 & 0 & 20 & P.S.2 & 229 & 91.1923 \\
\hline $\mathbf{3 1}$ & 26 & 10 & 10 & 10 & P.S.2 & 39 & 98.5 \\
\hline $\mathbf{3 3}$ & 27 & 10 & 10 & 10 & P.S.2 & 30 & 98.8462 \\
\hline $\mathbf{2 1}$ & 28 & 20 & 20 & 10 & P.S.2 & 0 & 100 \\
\hline $\mathbf{1 0}$ & 29 & 10 & 20 & 0 & GOx.2 & 137 & 94.7308 \\
\hline $\mathbf{1 4}$ & 30 & 10 & 10 & 10 & GOx.2 & 50 & 98.0769 \\
\hline $\mathbf{1}$ & 31 & 0 & 0 & 10 & GOx.2 & 147 & 94.3462 \\
\hline $\mathbf{2 2}$ & 32 & 0 & 10 & 0 & P.S.2 & 26 & 99 \\
\hline $\mathbf{1 2}$ & 33 & 10 & 20 & 20 & GOx.2 & 131 & 94.9615 \\
\hline $\mathbf{3 0}$ & 34 & 10 & 10 & 10 & P.S.2 & 7 & 99.7308 \\
\hline
\end{tabular}

\subsection{Data Analysis}

Analysis of variance (ANOVA) is used to determine the significance of the model. "Model F-value" of 45.64 and there is a $0.01 \%$ probability that this F-value of magnitude occurs due to noise. A very low probability value ( $p$-value $<0.0001)$ suggests that the model is strongly significant over the $95 \%$ confidence interval (i.e., $p$-values less than 0.05 indicate significance). The results of Table. 4 assert the importance of the variables is as follows: Amoxicillin> Persulfate> Glucose oxidase. In other words, the first agent has the most substantial impact, which may be originated from the fact that the driving force is the highest at first. Another interpretation may be different interactions that are generated during experiments by adding other components. The interactions are complex owing to the fact that in the current system presence of $\mathrm{NaOCl}$ in samples and pH range of 8-9 can have effects on this trend. Higher

efficiencies of $\mathrm{H}_{2} \mathrm{O}_{2}$ and

$$
\text { Persulfate }\left(\mathrm{S}_{2} \mathrm{O}_{8}^{2-}\right)
$$

are reported in solutions with lower pH values [21]. However, an increase in $\mathrm{pH}$ commonly accelerates persulfate decomposition due to boosting the formation of reactive surface hydroxo complexation. [13]. According to [22,23] the existence of $\mathrm{Cl}^{-}$would inhibit the oxidation of organics. Shreds of evidence state that chloride ions could influence the selectivity 
of radical species and their distribution, and increase the amount of the sum of radical species. Meanwhile, persulfate based oxidation processes can modify the effect of $\mathrm{Cl}^{-}$[24] a similar study on the chloride, and $\mathrm{pH}$ reveal that chloride level up to $5 \mathrm{mM}$ had a marginal effect on the reaction kinetics. Kinetics modeling as well recommended that $\mathrm{SO}_{4}{ }^{\cdot}{ }^{-}$converted to $\mathrm{HO} \cdot$ and $\mathrm{CO}_{3}{ }^{\cdot-}$ at upper pHs [13].

Both bacteria and antibiotics show $\mathrm{pH}$-dependent behavior through the bacterial enzyme stability and kinetics, the stability and kinetics of the antibiotics and the permeability of the bacterial membranes [25]. At room temperature, amoxicillin has $\mathrm{pK}_{\mathrm{a} 1}=2.74$ and $\mathrm{pK}_{\mathrm{a} 2}=6.98$. At a high $\mathrm{pH}$ value, the hydrolysis of the amoxicillin is observed [26].

Future works can investigate the functionality of the similar formulations without $\mathrm{NaOCl}$ and the observations the significance of each factor and their interactions. Out of six binary interactions, the one about amoxicillin and persulfate have the highest synergy with each other, and the importance of double interactions, respectively: $A B>B D>C D>A C>A D>B C$.

Table.4 ANOVA of the variables and the fitted model 


\begin{tabular}{|l|r|r|r|r|r|r|}
\hline \multicolumn{1}{|c|}{ Source } & Sum of Squares & df & Mean Square & F-value & \multicolumn{2}{c|}{ p-value } \\
\hline Model & $1.622 \mathrm{E}+05$ & 25 & 6489.32 & 45.64 & $<0.0001$ & significant \\
\hline A-AMOX & 15400.12 & 1 & 15400.12 & 108.30 & $<0.0001$ & \\
\hline B-P.S. & 4656.12 & 1 & 4656.12 & 32.74 & 0.0004 & \\
\hline C-GOx & 253.13 & 1 & 253.13 & 1.78 & 0.2189 & \\
\hline D-Order & 1144.90 & 1 & 1144.90 & 8.05 & 0.0219 & \\
\hline AB & 13778.00 & 1 & 13778.00 & 96.89 & $<0.0001$ & \\
\hline AC & 6903.13 & 1 & 6903.13 & 48.55 & 0.0001 & \\
\hline AD & 3321.13 & 1 & 3321.13 & 23.36 & 0.0013 & \\
\hline BC & 406.13 & 1 & 406.13 & 2.86 & 0.1295 & \\
\hline BD & 10878.13 & 1 & 10878.13 & 76.50 & $<0.0001$ & \\
\hline CD & 8001.13 & 1 & 8001.13 & 56.27 & $<0.0001$ & \\
\hline$A^{2}$ & 928.42 & 1 & 928.42 & 6.53 & 0.0339 & \\
\hline B $^{2}$ & 10315.79 & 1 & 10315.79 & 72.54 & $<0.0001$ & \\
\hline C & 11450.66 & 1 & 11450.66 & 80.53 & $<0.0001$ & \\
\hline ABC & 0.0000 & 0 & & & & \\
\hline ABD & 25538.00 & 1 & 25538.00 & 179.59 & $<0.0001$ & \\
\hline ACD & 210.13 & 1 & 210.13 & 1.48 & 0.2588 & \\
\hline BCD & 13695.13 & 1 & 13695.13 & 96.31 & $<0.0001$ & \\
\hline & & & & & & \\
\hline
\end{tabular}




\begin{tabular}{|l|r|r|r|r|r|r|}
\hline $\mathbf{A}^{2} \mathbf{B}$ & 3510.56 & 1 & 3510.56 & 24.69 & 0.0011 & \\
\hline $\mathbf{A}^{2} \mathbf{C}$ & 812.25 & 1 & 812.25 & 5.71 & 0.0439 & \\
\hline $\mathbf{A}^{2} \mathbf{D}$ & 4206.51 & 1 & 4206.51 & 29.58 & 0.0006 & \\
\hline $\mathbf{A B}^{2}$ & 30537.56 & 1 & 30537.56 & 214.75 & $<0.0001$ & \\
\hline $\mathbf{A C}^{\mathbf{2}}$ & 0.0000 & 0 & & & & \\
\hline $\mathbf{B}^{2} \mathbf{C}$ & 0.0000 & 0 & & & & \\
\hline $\mathbf{B}^{2} \mathbf{D}$ & 736.19 & 1 & 736.19 & 5.18 & 0.0525 & \\
\hline $\mathbf{B} \mathbf{C}^{2}$ & 0.0000 & 0 & & & & \\
\hline $\mathbf{C}^{2} \mathbf{D}$ & 1321.06 & 1 & 1321.06 & 9.29 & 0.0159 & \\
\hline $\mathbf{A}^{\mathbf{3}}$ & 0.0000 & 0 & & & & \\
\hline $\mathbf{B}^{3}$ & 0.0000 & 0 & & & & \\
\hline $\mathbf{C}^{3}$ & 0.0000 & 0 & & & & \\
\hline $\mathbf{A}^{2} \mathbf{B D}$ & 17622.56 & 1 & 17622.56 & 123.93 & $<0.0001$ & \\
\hline $\mathbf{A}^{2} \mathbf{C D}$ & 756.25 & 1 & 756.25 & 5.32 & 0.0500 & \\
\hline $\mathbf{A B} \mathbf{B}^{2} \mathbf{D}$ & 2475.06 & 1 & 2475.06 & 17.41 & 0.0031 & \\
\hline $\mathbf{A C} \mathbf{C}^{2} \mathbf{D}$ & 0.0000 & 0 & & & & \\
\hline Pure Error & 1137.60 & 8 & 142.20 & & & \\
\hline Cor Total & $1.634 \mathrm{E}+05$ & 33 & & & & \\
\hline
\end{tabular}

\subsection{Diagnostic tests}

Figure 3 shows that the values predicted by the model and the results obtained by the experiments for microbial load and disinfection efficiency are evenly distributed in a $45^{\circ}$ line. Moreover, the data points are more concentrated over high values for disinfection efficiency and low values for bacterial counts, respectively. The coefficient of determination $\left(R^{2}\right)$ and Adjusted $R^{2}$ are very close to the unity $(0.993)$ and 0.9713 , respectively. The signal-to-noise ratio is determined by Adeq. Precision where values above 4 are desirable. Here, the value of 26.2757 provides further support for a precise correlation between the actual and the predicted values. The low magnitude of the coefficient of variation (C.V. $\%=0.4721)$ and standard deviation $($ Std. Dev. $=0.4586)$ for disinfection efficiency demonstrates the dependability and reproducibility of the model.

According to Cook's distance test from Fig. 3, no data with a distance of more than one is observed, and as a result, there is no data whose exclusion caused a significant change in the model. The average leverage index is obtained by dividing the number of model expressions by the number of experiments. 
The leverage index of a data increases by repeating or adding points in its neighborhood and is quantitatively between zero and one. The last clue in this section is that, at points where the leverage index is one, the matching of the experimental result with the predicted value is the highest.

Perturbation analysis is used to determine the sensitivity of the responses to each of the factors in the design space. Fig. 4 shows the effects of the factors at the center point for both microbial load and disinfection efficiency in the case of the application of formulation types I and II. The slopes of lines and the curvature of the graphs indicate that in all cases the responses are sensitive to the amount of amoxicillin, glucose oxidase, and ammonium persulfate. The qualitative description states that with formulation type I, the effect of amoxicillin and persulfate on the responses will be similar and the slope will be different. With formulation type II, the slope and trend of changes related to amoxicillin and glucose oxidase are almost the same, and the effect of persulfate on the responses is greater than that of glucose oxidase. The quantitative explanation says that the positive slope of glucose oxidase and the negative slope of persulfate and amoxicillin reveals a hint that toward achieving higher efficiency in disinfection, more glucose oxidase and less amount of persulfate and amoxicillin are required. With formulation type II, the negative slope of glucose oxidase and amoxicillin and the positive slope of persulfate show that to achieve higher efficiency in disinfection, less glucose oxidase and amoxicillin are needed and more persulfate is needed. When antibacterial agents are combined, different interactions may occur, with various effects that may be synergistic, antagonistic, or additive [15]. The results imply that the first and third components follow the same trend. This can be interpreted by the fact that these materials are facing a high and low population of microbes. Moreover, the required dosage of the second component is higher than the others. Since both glucose oxidase [27] and persulfate [28] have not only the ability to degrade bacterial community but also to remove amoxicillin. Therefore, a proportion of the second material is devoted to the elimination of the first component, which is valuable because of its prevention of antibiotic resistance.

\subsection{The effects of the variables on the responses}

2D contours describing the simultaneous effect of amoxicillin and persulfate on the disinfection efficiency, with glucose oxidase at the central point, are shown in Fig. 5. In type I: amoxicillin concentration range above $10 \mathrm{mg} / \mathrm{L}$ and concentrations above $4 \mathrm{mg} / \mathrm{L}$ for persulfate, can lead to efficiencies over $98 \%$ was obtained. Also, in the absence of amoxicillin, with doses higher than $5 \mathrm{mg} / \mathrm{L}$ persulfate oxidase $100 \%$ efficiency is achieved. In type II: in the amoxicillin concentration ranges above 3 $\mathrm{mg} / \mathrm{L}$ and concentrations above $11 \mathrm{mg} / \mathrm{L}$ for persulfate, efficiencies above $98 \%$ are obtained. 2D contours showing the simultaneous effect of the amounts of amoxicillin and glucose oxidase on disinfection efficiency while persulfate dose is at the central point is shown in Fig. 5. In formulation type I: a large region of the left half of the graph for amoxicillin and glucose oxidase concentration is achieved efficiencies above $98 \%$. Also, at concentrations less than $3.5 \mathrm{mg} / \mathrm{L}$ for amoxicillin, with dosages higher than $3.5 \mathrm{mg} / \mathrm{L}$ for glucose oxidase $100 \%$ disinfection efficiency can be reached. In formulation type II: in the range of amoxicillin concentration less than $14 \mathrm{mg} / \mathrm{L}$ and concentrations less than $14.5 \mathrm{mg} / \mathrm{L}$ for glucose oxidase enzyme, an efficiency of over $98 \%$ is obtained. The 2D contour shows the simultaneous 
effect of glucose oxidase and persulfate on the disinfection efficiency of amoxicillin at the central point in Fig. 5. In formulation 1: the range of glucose oxidase enzyme above $10 \mathrm{mg} / \mathrm{L}$ and concentrations less than $14 \mathrm{mg} / \mathrm{L}$ for persulfate efficiency above $98 \%$ are obtained. In type II: in the concentration range of persulfate above $3.5 \mathrm{mg} / \mathrm{L}$ and in each concentration of glucose oxidase, an efficiency of over $98 \%$ is obtained. In addition, oblique contour lines indicate that disinfection efficiency increases with decreasing glucose oxidase concentration and increasing persulfate concentration. Comparisons of Fig. 5e and f, can show that once GOx nanoparticles are used prior to persulfate, GOx increasing strongly affects the disinfection and it can act as an activator for persulfate, which in agreement with notifies that nonmetallic activation is more effective and economic than thermal, radiation or metal catalysis. They relate the synergistic effect with accumulated electrons and free radicals [29].

\subsection{Validation and Optimization}

In model validation, the capability of the model to predict the actual results is measured. The software default is for the $95 \%$ confidence interval $(\mathrm{Cl})$. The confidence interval actually specifies two upper and lower limits for the average population (or an output). According to the results of Table.5, the average data and the observed data are in the $95 \%$ confidence interval. Table. 5 shows the tolerance interval (TI). It is considered as a fraction of individual responses ( $99 \%$ here) in the range of 0 to 100 and has a larger interval than the confidence interval to be able to observe the observed and unobserved changes in considered and defined as a fraction of all outputs. If the model was required to be converted, the median would be achieved more than the actual average. Herein, the median of the original mean and no conversion is applied.

Table.5 Validating the performance of the multi-oxidant formulation

\begin{tabular}{|c|c|c|c|c|c|c|c|c|c|}
\hline Analysis & $\begin{array}{c}\text { Predicted } \\
\text { Mean }\end{array}$ & $\begin{array}{l}\text { Predicted } \\
\text { Median }\end{array}$ & $\begin{array}{c}\text { Obser } \\
\text { ved }\end{array}$ & $\begin{array}{l}\text { Std. } \\
\text { Dev }\end{array}$ & SE Mean & $\begin{array}{l}95 \% \mathrm{CI} \\
\text { low for } \\
\text { Mean }\end{array}$ & $\begin{array}{l}95 \% \mathrm{CI} \\
\text { high for } \\
\text { Mean }\end{array}$ & $\begin{array}{c}95 \% \mathrm{TI} \\
\text { low for } \\
99 \% \text { Pop }\end{array}$ & $\begin{array}{l}95 \% \mathrm{TI} \\
\text { high for } \\
99 \% \text { Pop }\end{array}$ \\
\hline $\begin{array}{l}\text { Bacterial } \\
\text { Counts }\end{array}$ & 114.8 & 114.8 & 131 & 42.8976 & 19.1844 & 70.5608 & 159.039 & -109.936 & 339.536 \\
\hline $\begin{array}{l}\text { Disinfection } \\
\text { Efficiency }\end{array}$ & 84.9935 & 84.9935 & 86.143 & 5.60752 & 2.50776 & 79.2106 & 90.7764 & 55.6162 & 114.371 \\
\hline
\end{tabular}

To determine the optimum conditions for the cooling tower disinfection, the optimization tool of DesignExpert ${ }^{\circledR} 13.0 .1$ was utilized. The program strategy was to optimize the response via the maximization of an objective function named the desirability function ranging from zero to one. Once desirability functions turn into one, the program explored the circumstances in which desirability reached a maximum level. To achieve the optimum conditions, four times the program is recalled. The first two trials have been devoted to formulation types I and II where all the factors were selected "within the range" while R1 (Bacterial Counts) and R2 (Disinfection efficiency) were defined as with target to zero and 
maximum, respectively. The 3rd and 4th evaluations have the same settings but factor $\mathrm{C}$ is set as "minimum" to reduce the final cost of the formulation. GOx enzyme is the most expensive component in the formulations.

Table.6 Economic prioritization of optimized formulations

\begin{tabular}{|c|c|c|c|c|c|c|c|c|}
\hline $\begin{array}{l}\text { Optimization } \\
\text { Case Number }\end{array}$ & $\begin{array}{c}\text { AMOX } \\
\text { (Kg) }\end{array}$ & $\begin{array}{l}\text { P.S. } \\
\text { (Kg) }\end{array}$ & $\begin{array}{l}\mathrm{GOx} \\
(\mathrm{Kg})\end{array}$ & Order & $\begin{array}{c}\text { Bacterial } \\
\text { Counts }\end{array}$ & $\begin{array}{c}\text { Disinfection } \\
\text { Efficiency }\end{array}$ & Desirability & $\begin{array}{c}\text { Cost } \\
\text { (\$) }\end{array}$ \\
\hline 4 & 9.735 & 0.282 & 0 & P.S 2 & 0.092 & 99.996 & 1.000 & 35.723 \\
\hline 3 & 0 & 38.109 & 2.628 & GOx.2 & 14.626 & 99.437 & 0.950 & 134.179 \\
\hline 2 & 16.107 & 21.246 & 0.402 & P.S. 2 & 0.000 & 100.000 & 1.000 & 104.79 \\
\hline 1 & 2.373 & 36.03 & 3.794 & GOx. 2 & 0.000 & 100.000 & 1.000 & 377.447 \\
\hline
\end{tabular}

As the final clue of this process, the composition of formulation, the associated disinfection efficiencies, and costs of optimum options which are most economical are given in Table.6. Accordingly, the most economical options are as follows: a binary formulation type I achieved $100 \%$ efficiency at a cost of 134.179\$. While a triple formulation type II resulted in $100 \%$ and cost $104.79 \$$ and finally, a binary formulation of amoxicillin and persulfate can dampen the expenses to a very considerable extent. If case 4 would be applied to a volume $3000 \mathrm{~m}^{3}$, it only costs 36 dollars. Given that each cooling tower has about one-eighth of this volume, 4.5 dollars is predicted to be enough and once a promising result is achieved, It can be applied to more towers. Meanwhile, the flexibility of formulations with several options can allow us to use different dosages and shock modes. The optimization ramps settings, a bar graph of 2D contours of the first option for the 4th case of the optimization are shown in Fig. 6. Accordingly, the highest level for efficiencies above $97 \%$ is related to the double interaction: amoxicillin and glucose oxidase > persulfate and glucose oxidase > amoxicillin and persulfate, respectively.

\section{Conclusion}

Disinfection of the cooling tower water is an issue of worldwide importance. Although, not all sections in the cooling tower unit are subjected to a uniform bacterial community. The present study indicated that the $\mathrm{NaOCl}$ injection in the basin is not a comprehensive approach for disinfection of the inner compartment of the towers. Dosages above $20 \mathrm{mg} / \mathrm{l}$ of single utilization of GOx, amoxicillin, and persulfate have been proved their effectiveness toward nearly $100 \%$ disinfection. Pre-scale-up tests confirmed no need for mixing tools for the distribution and employment of the multi-oxidant formulation. In an attempt to reduce material consumptions at an industrial scale and more importantly preventing bacterial resistance, an experimental design of RSM combined with BBD has been carried out. Since the interactions are complex, the order of addition of each component is considered as an independent variable and accordingly, formulations are categorized into types I and II. According to ANOVA, the importance of factors is Amoxicillin> Persulfate> Glucose oxidase. the results show first and third components behave like each other that these biocide substances face a high and low populations of microbes. Moreover, the required dosage of the second component is higher than the others. The most 
economic result, which is predicted is ascribed to a binary formulation type II of $9.735 \mathrm{Kg}$ amoxicillin and $0.282 \mathrm{Kg}$ persulfate can disinfect a volume of $3000 \mathrm{~m}^{3}$ with $>99.99 \%$.

\section{References}

1. Iervolino, M., B. Mancini, and S. Cristino, Industrial Cooling Tower Disinfection Treatment to Prevent Legionella spp. International journal of environmental research and public health, 2017. 14(10): p. 1125.

2. Pinel, I.S.M., et al., Efficient cooling tower operation at alkaline $\mathrm{pH}$ for the control of Legionella pneumophila and other pathogenic genera. Water Research, 2021. 197: p. 117047.

3. Pinel, I.S.M., et al., Bacterial community dynamics and disinfection impact in cooling water systems. Water Research, 2020. 172: p. 115505.

4. Narenkumar, J., et al., Role of 2-mercaptopyridine on control of microbial influenced corrosion of copper CW024A metal in cooling water system. Chemosphere, 2019. 222: p. 611-618.

5. Lin, Q., et al., Sanitizing agents for virus inactivation and disinfection. VIEW, 2020. 1(2): p. e16.

6. Craig, W.A., Overview of newer antimicrobial formulations for overcoming pneumococcal resistance. The American Journal of Medicine Supplements, 2004. 117(3, Supplement 1): p. 16-22.

7. Sonthipet, S., S. Ruenphet, and K. Takehara, Bactericidal and virucidal efficacies of potassium monopersulfate and its application for inactivating avian influenza virus on virus-spiked clothes. The Journal of veterinary medical science, 2018. 80(4): p. 568-573.

8. McDonnell, G., The Use of Hydrogen Peroxide for Disinfection and Sterilization Applications. PATAl'S Chemistry of Functional Groups, 2014: p. 1-34.

9. Yu, L., et al., A Field Pilot Study on Treating Groundwater Contaminated with Sulfolane Using UV/H2O2. Water, 2020. 12(4).

10. Sood, G., et al., A pilot observational study of hydrogen peroxide and alcohol for disinfection of privacy curtains contaminated by MRSA, VRE and Clostridium difficile. J Infect Prev, 2014. 15(5): p. 189193.

11. Moretro, T., et al., Whole room disinfection with hydrogen peroxide mist to control Listeria monocytogenes in food industry related environments. Int J Food Microbiol, 2019. 292: p. 118-125.

12. Shoabargh, S., et al., A hybrid photocatalytic and enzymatic process using glucose oxidase immobilized on TiO2/polyurethane for removal of a dye. Journal of Industrial and Engineering Chemistry, 2014. 20(5): p. 3150-3156. 
13. Li, W., et al., Mechanisms on the Impacts of Alkalinity, pH, and Chloride on Persulfate-Based Groundwater Remediation. Environmental Science \& Technology, 2017. 51(7): p. 3948-3959.

14. Lee, J., U. von Gunten, and J.-H. Kim, Persulfate-Based Advanced Oxidation: Critical Assessment of Opportunities and Roadblocks. Environmental Science \& Technology, 2020. 54(6): p. 3064-3081.

15. Park, K.M., et al., The Bactericidal Effect of a Combination of Food-Grade Compounds and their Application as Alternative Antibacterial Agents for Food Contact Surfaces. Foods, 2020. 9(1).

16. Medina-Rodríguez, A.C., et al., Clean-in-place disinfection of dual-species biofilm (Listeria and Pseudomonas) by a green antibacterial product made from citrus extract. Food Control, 2020. 118: $\mathrm{p}$. 107422.

17. Sharma, G., et al., Role of glucose oxidase in combination with antibiotics on ocular pathogens. Indian Journal of Ophthalmology, 1984. 32(5): p. 427-428.

18. Liu, Y., et al., Disinfection of bacterial biofilms in pilot-scale cooling tower systems. Biofouling, 2011. 27(4): p. 393-402.

19. Sohrabi, S. and F. Akhlaghian, Modeling and optimization of phenol degradation over copper-doped titanium dioxide photocatalyst using response surface methodology. Process Safety and Environmental Protection, 2016. 99: p. 120-128.

20. Liu, J., et al., Effects of glucose oxidase on growth performance, immune function, and intestinal barrier of ducks infected with Escherichia coli O88. Poultry Science, 2020. 99(12): p. 6549-6558.

21. Gonçalves, N.P.F., et al., Photo-activation of persulfate and hydrogen peroxide by humic acid coated magnetic particles for Bisphenol A degradation. Catalysis Today, 2021. 361: p. 43-49.

22. Afzal, A., et al., Decomposition of cyclohexanoic acid by the UV/H2O2 process under various conditions. Science of The Total Environment, 2012. 426: p. 387-392.

23. Moraes, J.E.F., et al., Treatment of Saline Wastewater Contaminated with Hydrocarbons by the PhotoFenton Process. Environmental Science \& Technology, 2004. 38(4): p. 1183-1187.

24. Fang, G.-D., et al., Sulfate radical-based degradation of polychlorinated biphenyls: Effects of chloride ion and reaction kinetics. Journal of Hazardous Materials, 2012. 227-228: p. 394-401.

25. Falagas, M.E., L. McDermott, and D.R. Snydman, Effect of $\mathrm{pH}$ on in vitro antimicrobial susceptibility of the Bacteroides fragilis group. Antimicrobial Agents and Chemotherapy, 1997. 41(9): p. 2047-2049.

26. I.M. Bezerra, O.C.-f., S.Mattedi, Solid- liquid equilibrium data of amoxicillin and hydroxyphenylglycine in aqueous media. Brazilian Journal of Chemical Engineering, 2013. 30: p. 45-54. 
27. Sohrabi, S., M. Keshavarz Moraveji, and D. Iranshahi, A low temperature synthesis of Ti/TiO2/Fatty Acid/GOx/ZnO and its evaluation for amoxicillin bio-photo-catalytic degradation. Journal of Molecular Liquids, 2021. 343: p. 116979.

28. Kattel, E., et al., Persulfate-based photodegradation of a beta-lactam antibiotic amoxicillin in various water matrices. Environmental Technology, 2020. 41(2): p. 202-210.

29. Dou, M., et al., A novel in-situ chemical oxidation channel - Selective pH-dependence of refractory $\beta$ lactam antibiotics in the synergistic mechanism of persulfate and $g$-C3N4 under visible light. Chemical Engineering Journal, 2020. 394: p. 124899.

\section{Figures}
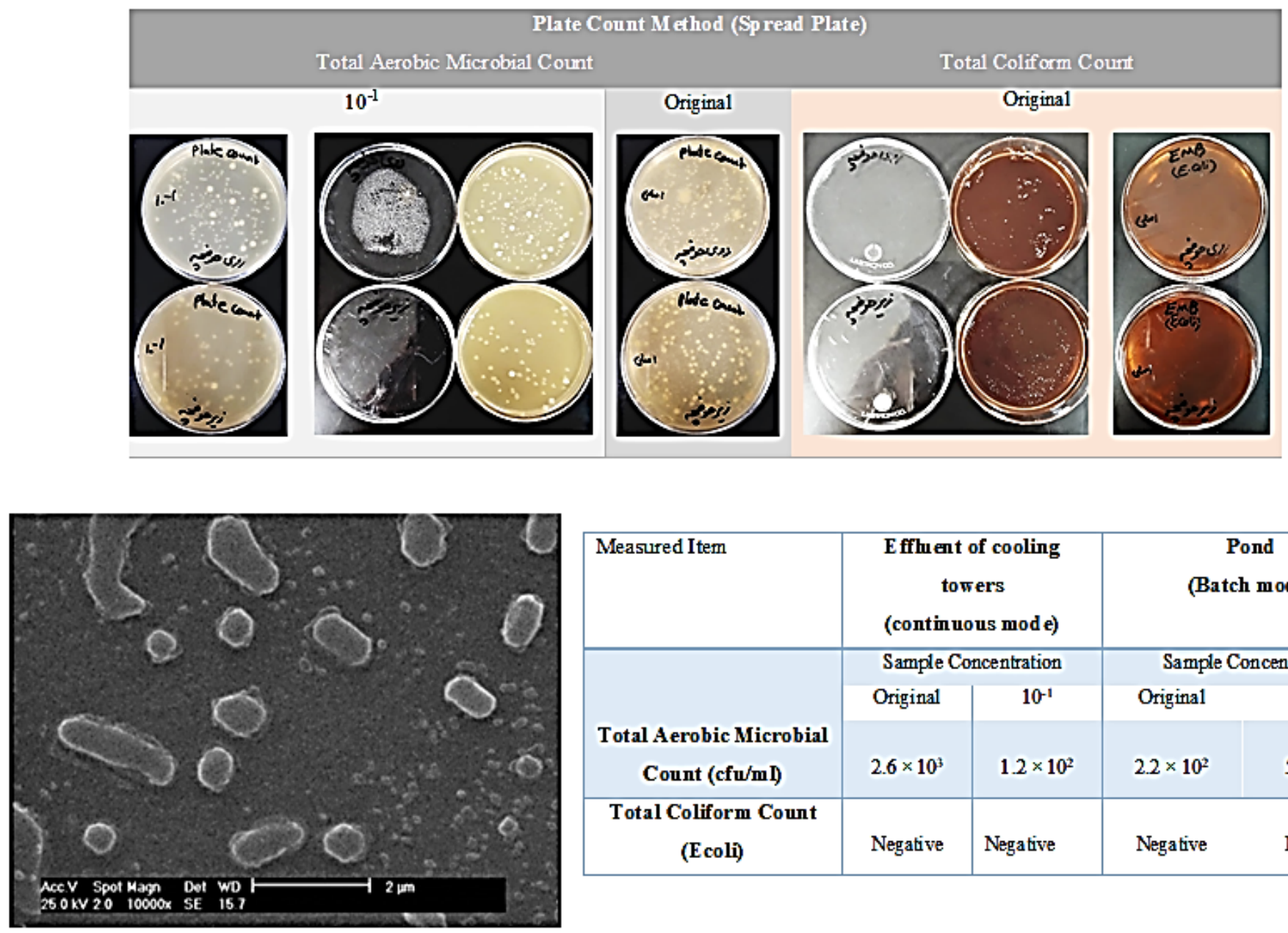

\begin{tabular}{|c|c|c|c|c|}
\hline Measured Item & \multicolumn{2}{|c|}{$\begin{array}{l}\text { E ffhent of cooling } \\
\text { towers } \\
\text { (continuous mode) }\end{array}$} & \multicolumn{2}{|c|}{$\begin{array}{c}\text { Pond } \\
\text { (Batch mode) }\end{array}$} \\
\hline & \multicolumn{2}{|c|}{ Sample Concentration } & \multicolumn{2}{|c|}{ Sample Concentration } \\
\hline & Original & $10^{-1}$ & Original & $10^{-1}$ \\
\hline $\begin{array}{c}\text { Total Aerobic Microbial } \\
\text { Count (cfu/mI) }\end{array}$ & $2.6 \times 10^{3}$ & $1.2 \times 10^{2}$ & $2.2 \times 10^{2}$ & $5.5 \times 10^{1}$ \\
\hline $\begin{array}{l}\text { Total Coliform Count } \\
\text { (Ecoli) }\end{array}$ & Negative & Negative & Negative & Negative \\
\hline
\end{tabular}

\section{Figure 1}

Plate figures of microbial colonies, SEM image of existing batteries in a water sample, and records of bacterial loads 


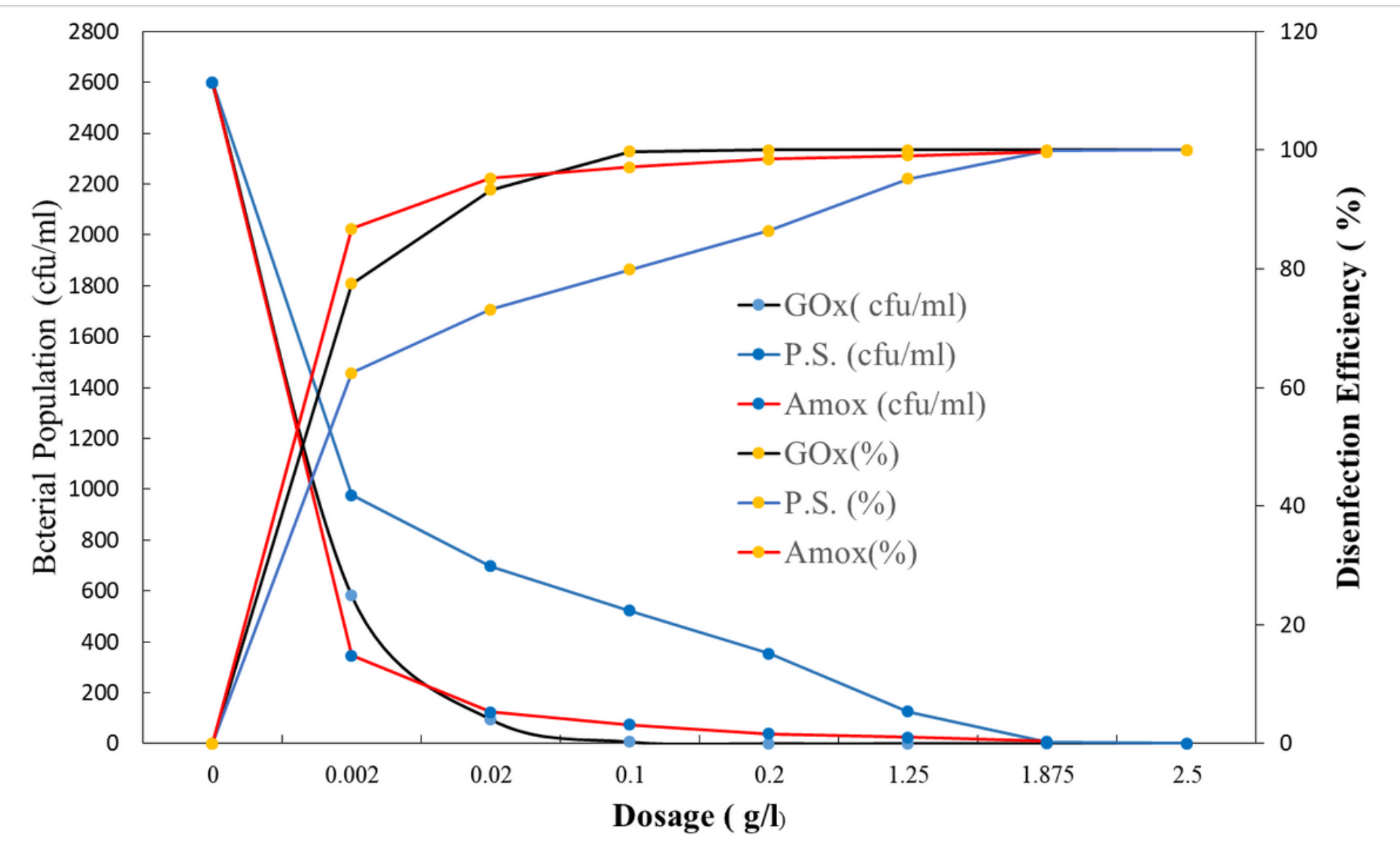

Figure 2

Single effects of formulation components on bacterial load and disinfection efficiency 

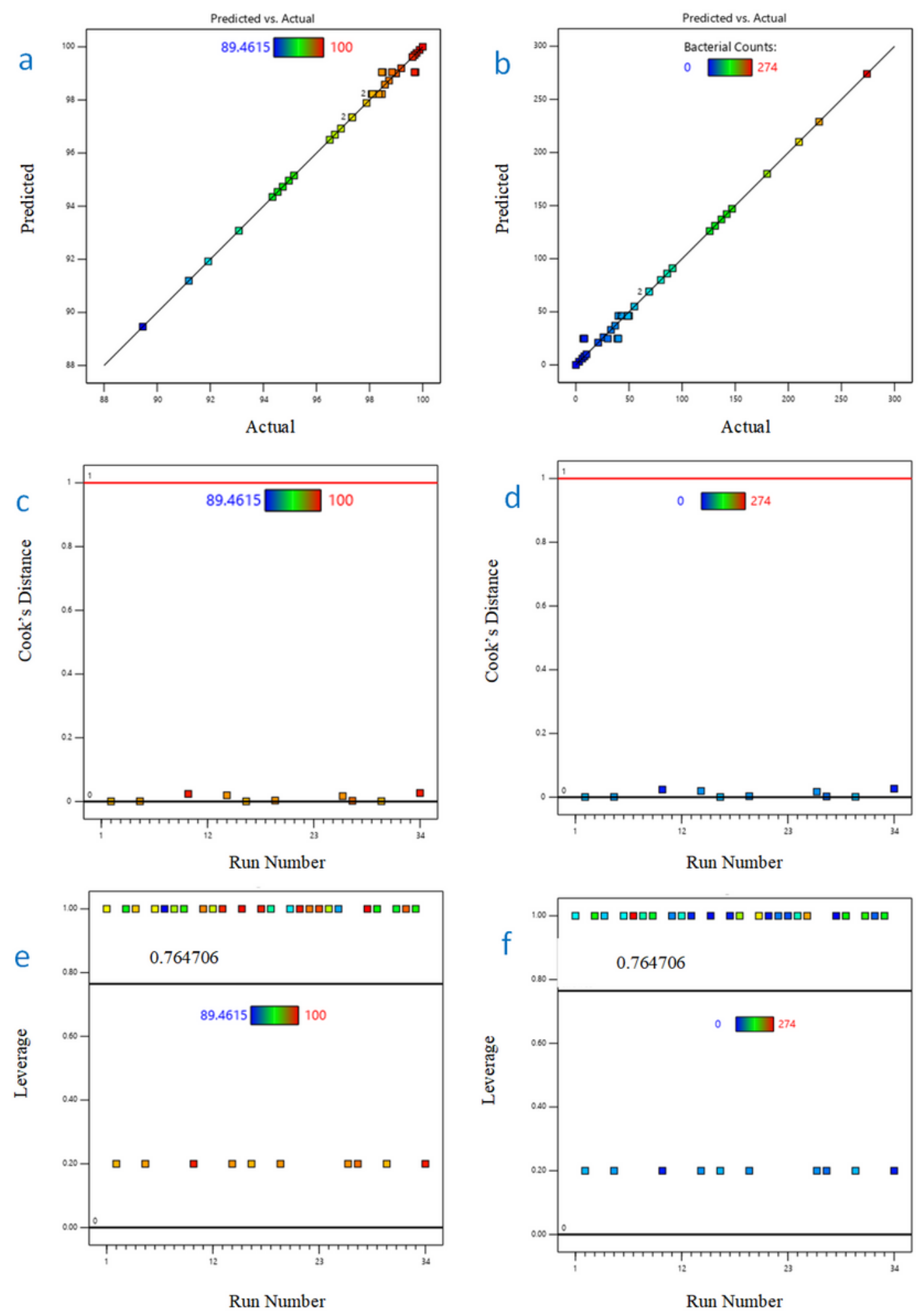

\section{Figure 3}

Diagnostic analyses for predicted vs. actual for a) disinfection efficiency, b) bacterial counts, cook's distance for c) disinfection efficiency, d) bacterial counts, leverage test for e) disinfection efficiency, f) bacterial counts 


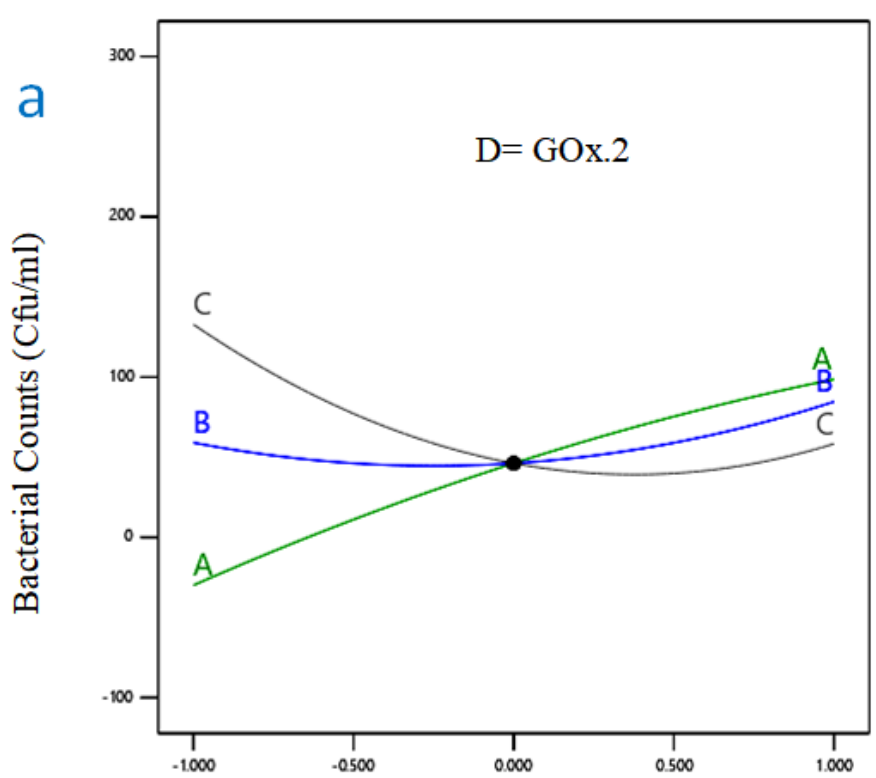

Deviation from Reference Point (Coded Units)

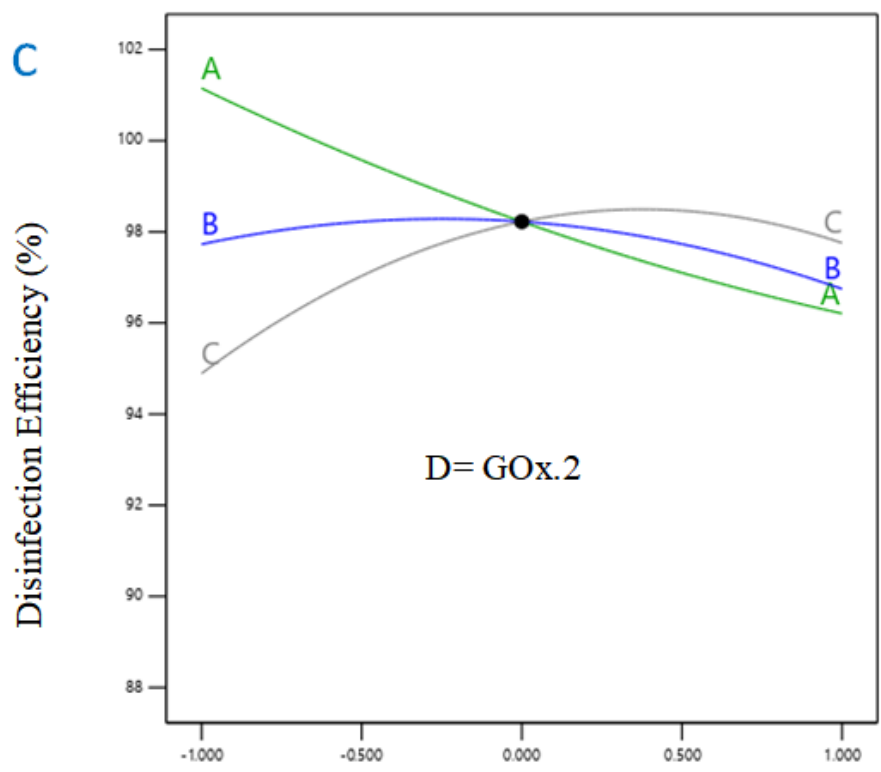

Deviation from Reference Point (Coded Units)

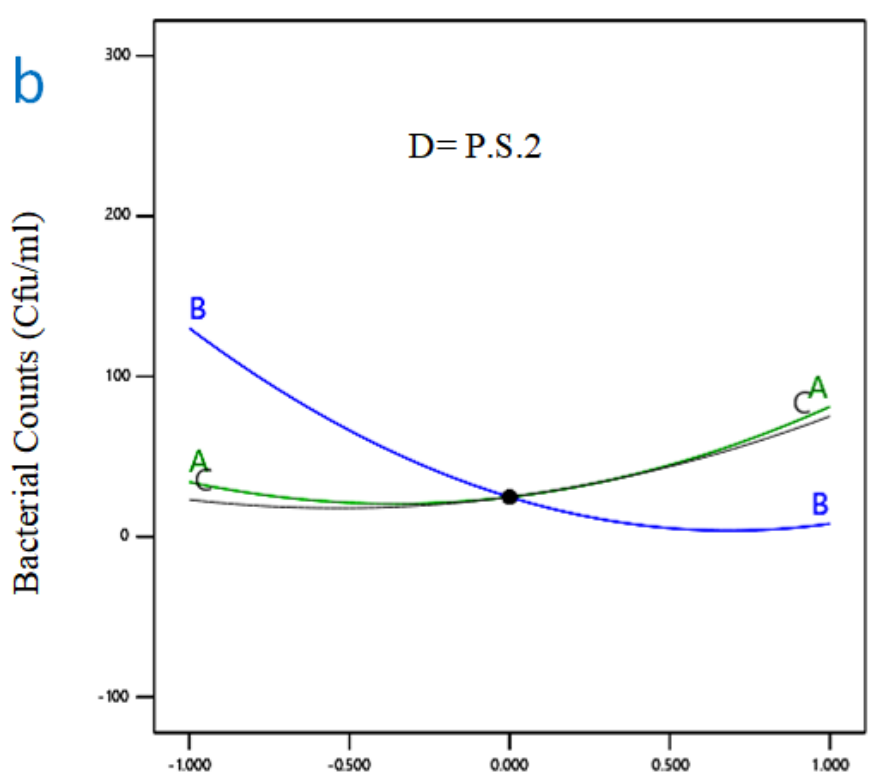

Deviation from Reference Point (Coded Units)

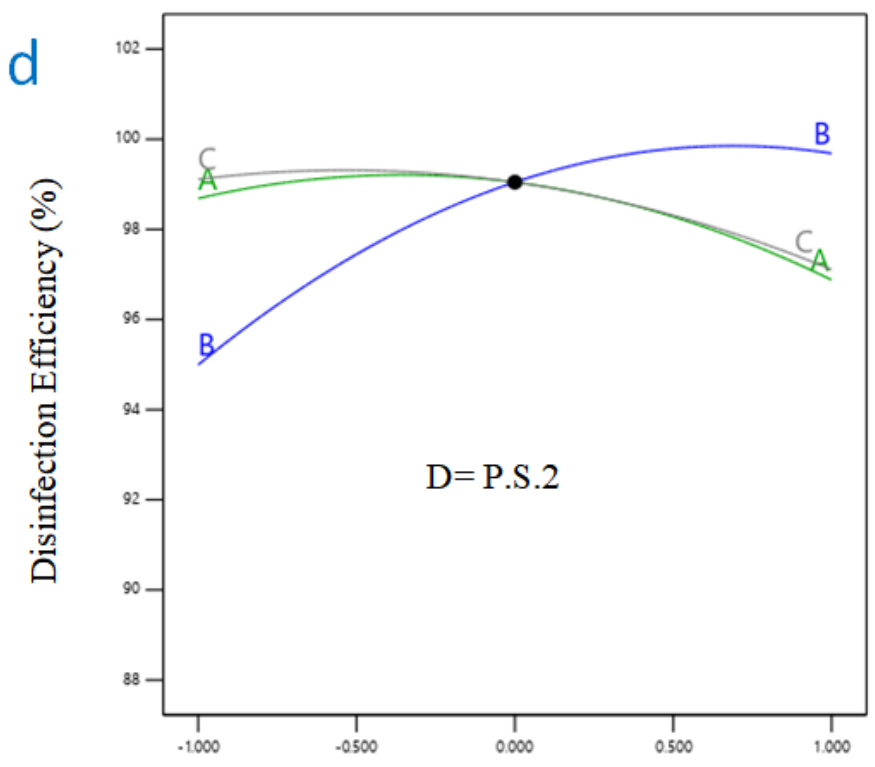

Deviation from Reference Point (Coded Units)

\section{Figure 4}

Perturbation analysis for bacterial load with formulation a) type I, b) type II and disinfection efficiency with formulation c) type I, d) type II 


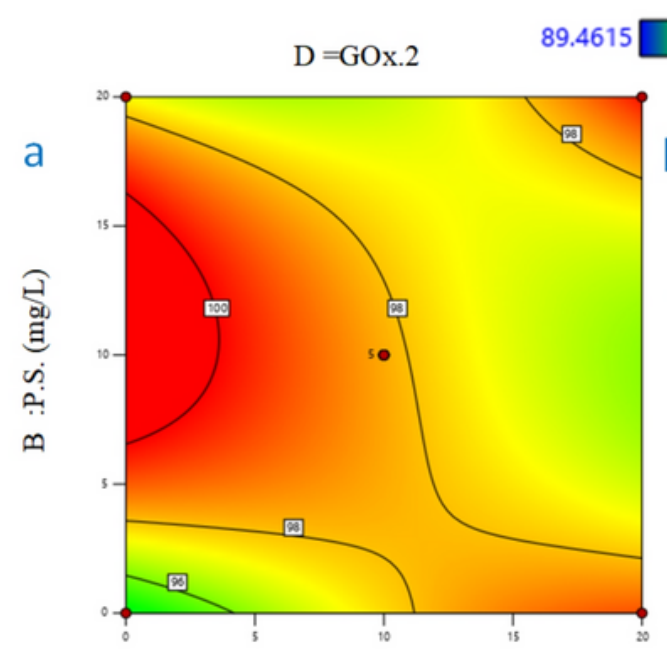

A :Amox. (mg/L)

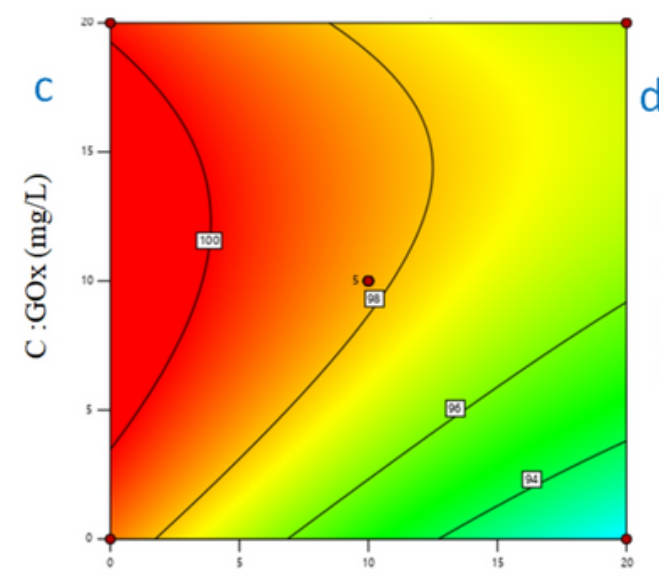

A :Amox. (mg/L)

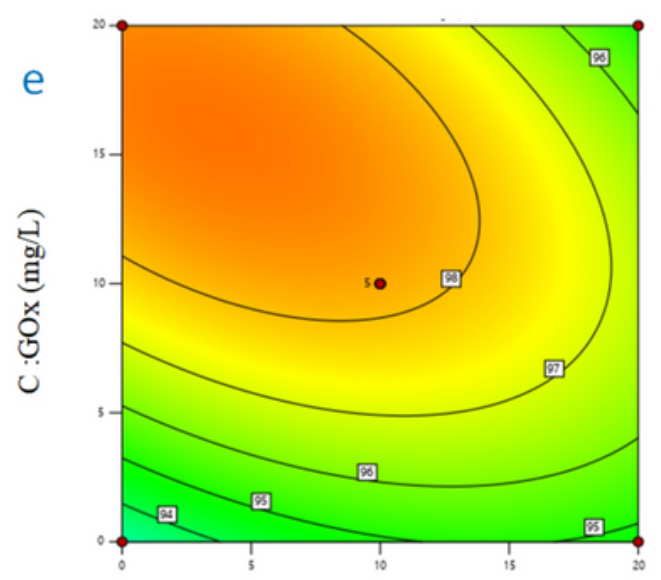

B :P.S. (mg/L)

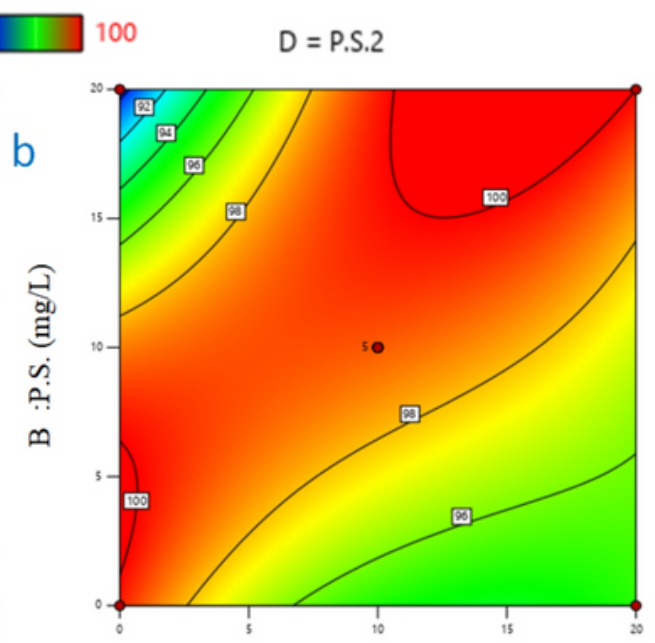

A :Amox. (mg/L)

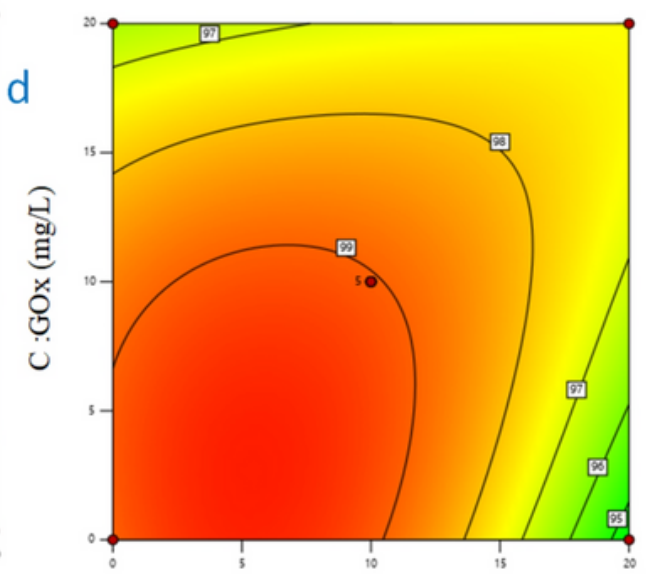

A :Amox. (mg/L)

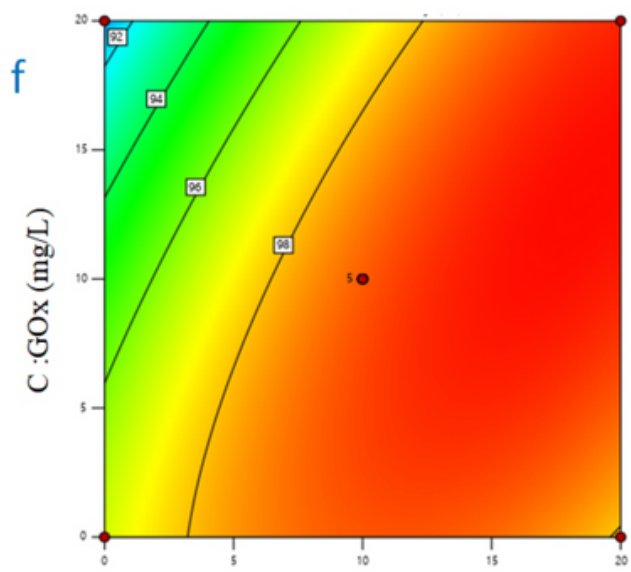

B :P.S. (mg/L)

\section{Figure 5}

Binary interactions in formulation type I a) $A B, C) A C$, e) $B C$ and type II b) $A B$ d) $A C$, f) $B C$ 
a
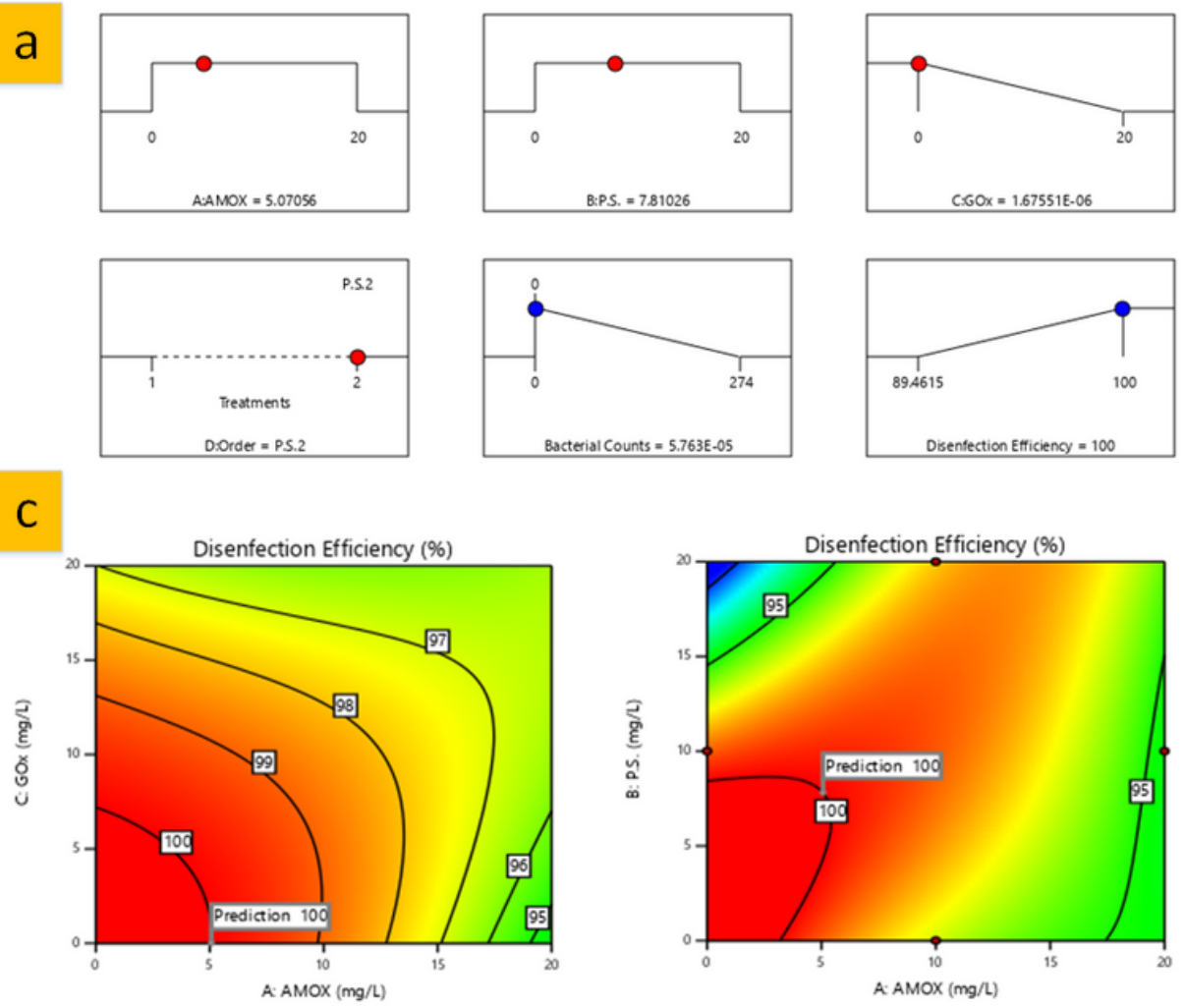

b
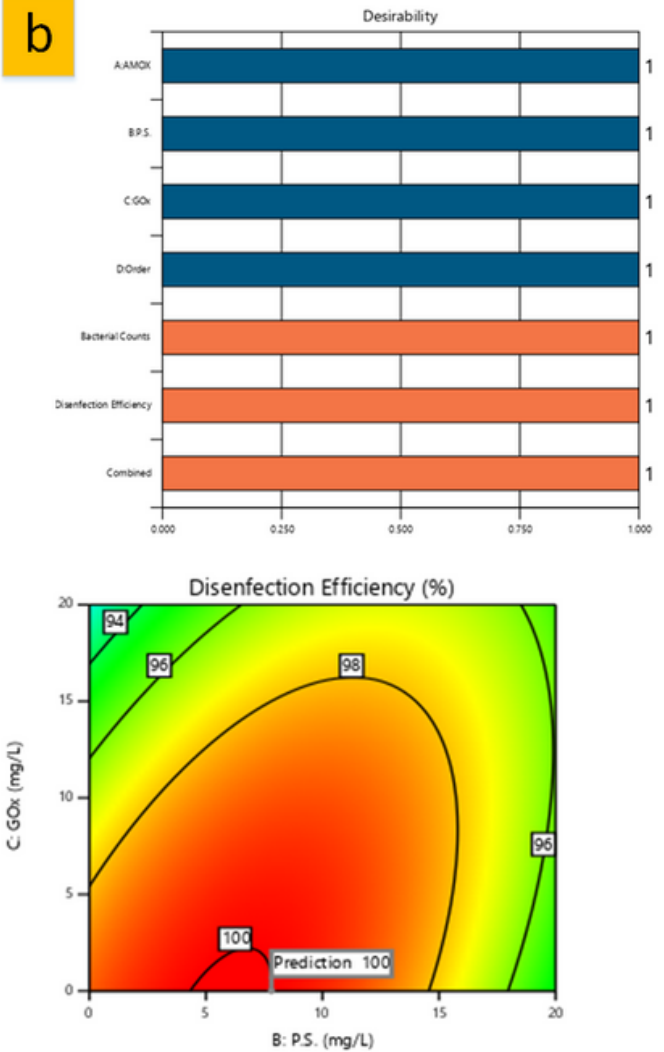

\section{Figure 6}

the first option in 4th case of optimizations, a) conditions b) desirability function, and c) binary interactions

\section{Supplementary Files}

This is a list of supplementary files associated with this preprint. Click to download.

- Scheme1.jpeg 